\title{
Report
}

\section{Development of Radiation Protection on TENORM}

\author{
Toshiso Kosako, ${ }^{* 1}$ Nobuyuki SugIURA, ${ }^{* 1}$ Hidenori YONEHARA, ${ }^{* 2}$ \\ Minoru OKOSHI ${ }^{* 3}$ and Kunihiro NAKAI ${ }^{* 4}$
}

(Received on March 3, 2005)

\begin{abstract}
Some of technologically enhanced naturally occurring radioactive material (TENORM), such as radon and monazite sand, gradually became a target for radiological protection. In order to regulate TENORM safely and economically, it is essential to consider the characteristics of TENORM such as ubiquity, huge volume, and very low activity levels. In this paper, radiation protection principles and standards for NORM/TENORM are summarized based on the reports published by the international organizations (e. g. ICRP and IAEA) to assist the development of national regulatory framework. The survey results on the present Japanese situations on industries related to NORM/TENORM are provided, and the categorization for NORM/TENORM, which is established by the Radiation Council of Japan, is explained how to control NORM/TENORM based on their exposure doses instead of their activity levels. Finally, basic processes to solve the problems related to NORM/TENORM are discussed.
\end{abstract}

KEY WORDS: NORM, radiological protection, practice, intervention, categorization.

\section{INTRODUCTION}

The natural background radiation had been out of the framework of radiological protection because of its natural occurrence. Some of technologically enhanced naturally occurring radioactive material (TENORM), such as radon and monazite sand, gradually became a target for radiological protection. In ICRP Publ. $60{ }^{1)}$ the following four natural sources were listed as part of occupational exposure:

-operations in workplaces where the radon concentration is high,

- operations with materials that contain significant traces of natural radionuclides,

- operation of jet craft, and

${ }^{* 1}$ Research Center for Nuclear Science and Technology, the University of Tokyo; 2-11-16, Yayoi, Bunkyo-ku, Tokyo 113-0032, Japan.

*2 Radon Research Group, Research Center for Radiation Safety, National Institute of Radiological Sciences; 4-9-1, Anagawa, Inage-ku, Chiba 263-8555, Japan.

*3 Department of Decommissioning and Waste Management, Japan Atomic Energy Research Institute; Tokai-mura, Naka-gun, Ibarakiken, 319-1195, Japan.

${ }^{* 4}$ Industrial Project Division, Radioactive Waste Management, Energy \& Environmental Project Department, JGC Corporation; 23-1, Minato Mirai, Nishi-ku, Yokohama 220-6001, Japan.
- space flight.

All of the above were considered to be controlled from the viewpoint of amenability to control.

The United Nations Scientific Committee on the Effects of Atomic Radiation (UNSCEAR) has accumulated a large amount of data on NORM/TENORM issues in a world-wide scale over a long period of time. It was reported in UNSCEAR 2000 ${ }^{2}$ that the public exposure could be enhanced by NORM, such as treatment or production of phopspheric acid, mineral ore, uranium mining, zircon sand, titanium pigment, fossil fuel, oil and its extraction, building material and so on.

On the other hand, the IAEA published the Basic Safety Standard (BSS) $)^{3)}$ in 1996 incorporated with the radiological protection principle of ICRP Publ. 60. In the BSS, the exemption levels for each radionuclide were proposed including natural radionuclides. Discussion for the introduction of BSS exemption levels into the regulatory system has commenced mainly in Europe and Japan. In the European discussion, the new concept of "work activity" was introduced and the 300 $\mu \mathrm{Sv} / \mathrm{y}$ of dose criteria was set instead of $10 \mu \mathrm{Sv} / \mathrm{y}$ for "practice." In the Japanese discussions, the direct application of the BSS exemption level to NORM is not appropriate and it is better to use the intervention exemption concept, which was introduced in ICRP Publ. 82.4)

In international movements related to NORM/TENORM 
situations, the Radioactive Waste Management Group in FNCA (Forum for Nuclear Cooperation in Asia) organized a TENORM subgroup for discussion/survey of NORM/ TENORM problems. The TENORM discussion meetings were held at Australia in February 2003, at Malaysia and Viet Nam in August 2003, and at China and Thailand in August 2004.

In the FNCA activity, the international concepts of radiation protection on TENORM were summarized. As for Japanese situation, the present status of NORM/TENORM recent utilization, the discussion of regulatory system on TENORM in the Radiation Council and some events related to TENORM were also summarized. This paper developed the radiation protection principles on TENORM as a leading paper of following five countries reports.

\section{INTERNATIONAL RADIATION PROTECTION CONCEPT FOR TENORM}

\subsection{ICRP}

\subsubsection{Exemption, exclusion and occupational exposure for natural radiation}

ICRP recommended the system of radiological protection in Publ. 60. ${ }^{1)}$ The system for proposed and continuing practices is based on the general principles which are the justification of a practice, the optimisation of protection, and individual dose and risk limits. The types of exposure are occupational exposure, medical exposure and public exposure. The system for intervention is based on the justification and the optimisation.

In the Publ. 60, ICRP defines that doses incurred in situations where the only available protective action takes the form of intervention are excluded from the scope of the dose limits. Radon in dwellings and in the open air and radioactive materials, natural or artificial, already in the environment, are example of situations that can be influenced only by intervention.

ICRP also describes exclusion and exemption from regulatory control and the basis for them in Publ. 60 .

In the Publ. 75 "General Principle for the Radiation Protection of Workers", ${ }^{\text {5) }}$ ICRP recommends the control of occupational exposure to natural sources such as Radon at work and materials with elevated levels of natural radionuclides. ICRP recommends that the action level for intervention in workplaces should be applied to the effective dose and should be in the range $3-10 \mathrm{mSv}$ in a year. As for materials with elevated levels of natural radionuclides, it is recommended that regulatory agencies choose activity concentrations of parent nuclides within the range $1-10 \mathrm{~Bq} / \mathrm{g}$ to determine whether the exposures from these materials should be regarded as occupational.

\subsubsection{Existing dose and intervention exemption level}

ICRP Publ. $82^{4)}$ provides guidance on the application of the system of radiological protection to situations of prolonged exposure to ionising radiation. In this publication, ICRP recommends the application of the system of radiological protection to practices resulting in prolonged exposure and to intervention in prolonged exposure situations, generic reference levels of existing annual dose for intervention, and application of the recommendations to specific prolonged exposure situations.

Generic reference levels for intervention, in terms of existing total annual doses, are given as $<\sim 100 \mathrm{mSv}$, above which intervention is almost always justifiable, and $<\sim 10$ $\mathrm{mSv}$, below which intervention is not likely to be justifiable. Intervention exemption levels for commodities, especially building materials, are expressed as an additional annual dose of $\sim 1 \mathrm{mSv}$. The dose limit for exposures of the public from practices is expressed as aggregated additional annual doses from all relevant practices of $1 \mathrm{mSv}$. Dose constraints for sources within practices are expressed as an additional annual dose lower than $1 \mathrm{mSv}$ (e. g. of $\sim 0.3 \mathrm{mSv}$ ), which could be $\sim 0.1 \mathrm{mSv}$ for the prolonged exposure component. An exemption level for practices is expressed as an additional annual dose of $\sim 0.01 \mathrm{mSv}$.

\subsection{IAEA}

\subsubsection{BSS (SS115)}

International Basic Safety Standards (BSS) for Protection against Ionizing Radiation and for the Safety of Radiation Sources published in 1996 as Safety Series No 115 of IAEA ${ }^{3)}$ has been widely introduced in the radiation protection policy in many countries. The principles of radiation protection in the BSS are generally based on ICRP Publ. 60. The principles on regulation of TENORM are also mentioned in the BSS according to the policy of the ICRP recommendation.

The BSS shall apply to practices involving exposure to natural sources specified by the regulatory authority. The natural sources within the scope of the BSS include those related to mines, mills, processing radioactive ores and other source specified by the authority. Exposure to natural sources shall normally be considered as a chronic exposure situation and shall be subjects to the requirements for intervention except some cases of public exposure related to practices and occupational exposure to radon. In the BSS, unmodified concentrations of radionuclides in most raw materials are deemed to be excluded from scope of the standards. This means that every material called as TENORM should be within the scope of the standards, if it can not be exempted. BSS provided criteria for exemption from the requirements of the standards for the regulation as practice. The exemption criteria is selected to be of order of $10 \mu \mathrm{Sv} / \mathrm{y}$ or less for the effective dose in any member of public and no more than 1 man $\cdot \mathrm{Sv}$ of collective effective dose. In the BSS exemption levels for both artificial and natural radionuclides are given which are derived by calculation according to above criteria. The value for natural thorium or uranium is selected to be 1 $\mathrm{Bq} / \mathrm{g}$ and that for ${ }^{40} \mathrm{~K}$ is $100 \mathrm{~Bq} / \mathrm{g}$. Because these values were derived with calculation in a scenario for a moderate quantity of material, BSS noted that unless the exposure is excluded, exemption for bulk amounts of materials with activity concentrations lower than the exemption levels given in the BSS may require further consideration by the regulatory authority. 


\subsubsection{RS-G-1.7 (DS161)}

In IAEA, coherent system for the concepts of exemption, exclusion and clearance has been discussed for a number of years. After IAEA was requested in the General Conference held in 2000, to discuss the establishment of the level for radioactive concentrations for the smooth international trade of commodities by the some countries which territories were contaminated by the Chernobyl accident, the Radiation Safety Standard Committee (RASSC) and the Waste Safety Standards Committee (WASSC) started to discuss this issue. From the results of discussions over a period of more than 3 years, a document of draft safety guide (draft No. DS161), entitled "Application of the Concepts of Exclusion, Exemption and Clearance" was approved by the Committees in March 2004 and published as Safety Series No. RS-G-1.76) in August 2004. The exclusion levels for radionuclides of natural origin and the exemption levels for radionuclides of artificial origin in bulk amount were provided in the document. As described above the exemption level given in the BSS can be applied only to the exemption of moderate quantities of materials which is considered to be less than 1 ton. Although the levels for artificial radionuclides were derived with calculation based on dose criteria of order $10 \mu \mathrm{Sv} / \mathrm{y}$ for normal situation of exposure and $1 \mathrm{mSv} / \mathrm{y}$ only for low probability events, those for natural radionuclides were derived using the concept of "exclusion" prescribed in BSS. The values were selected on the basis of consideration of upper end of the worldwide distribution in soil reported in UNSCEAR. The value for ${ }^{40} \mathrm{~K}$ was selected to be $10 \mathrm{~Bq} / \mathrm{g}$ and that for all other nuclides such as ${ }^{238} \mathrm{U}$ and ${ }^{232} \mathrm{Th}$ was $1 \mathrm{~Bq} / \mathrm{g}$. In relation to application of the values provided in the document, the values were selected for application to ordinary regulation of radioactive materials, to clearance level and to regulatory control in national and international trade of commodities.

2.3 European Commission : Radiation Protection No. 122 Part II

The European Commission (EC) published the report as Radiation Protection No. 122 Part II entitled "Practical use of the concepts of clearance and exemption (Part II)-Application of the concepts of exemption and clearance to natural radiation sources -" in 2002. ${ }^{7)}$ The objectives of this report are as follows;

-application of the concepts of exemption and clearance to natural radiation sources, and

- proposal of enveloping scenarios for establishing exemption and clearance values for naturally occurring radionuclides.

The exemption levels in the BSS are not applied to the large volumes of material processed and released by NORM industries, because they are derived only for moderate quantities (a few Mega-gram) of material. In the case of NORM industry, the amounts of material to be considered are in general very large both for exemption and for clearance, contrary to practices' for which clearance often relates to much larger volumes than exemption. For exemption and clearance, where appropriate, the same levels should be used for natu-

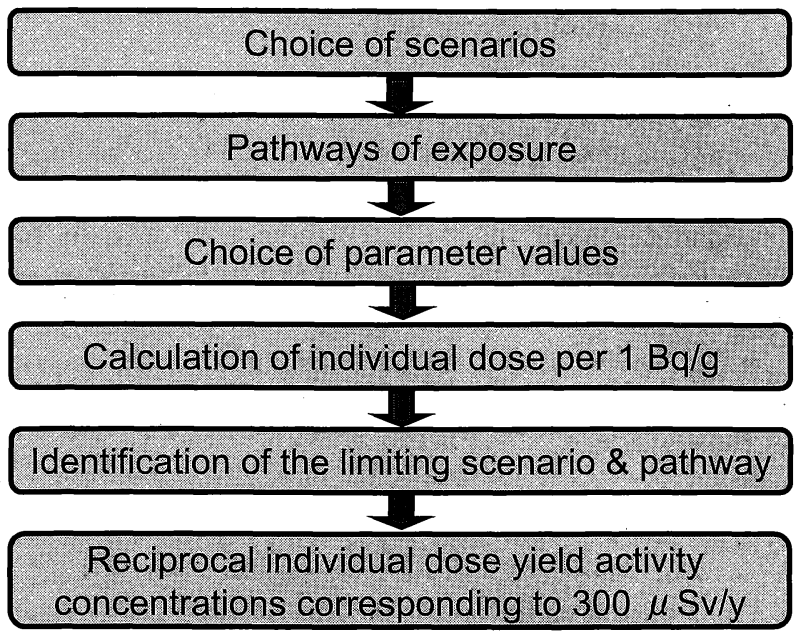

Fig. 1 The process of the derivation of exemption and clearance level for NORM.

rally occurring radionuclides.

EC RP 122 Part II deals with work activities. Work activities where the presence of natural radiation sources leads to a significant increase in the exposure of workers or members of the public and the material is not used because of its radioactive, fissile and fertile properties. Exposures by NORM industry are caused the following activities;

- Product of a process,

-Re-use of by-product material,

-Disposal of solid waste,

-Recycling of scales deposited on steel pipes (oil \& gas industry), and

-Atmospheric or liquid discharges.

The derivation of exemption and clearance levels for NORM is carried out through the process shown in Fig. 1.

In the derivation of exemption and clearance levels the following enveloping scenarios are considered:

-Transport over long/short distances (workers),

-Disposal on a heap or a landfill (workers),

-Person living in a house near a heap or landfill (members of the general public),

- Transport over long/short distances,

- Storage of moderate quantities, indoors,

- Storage of large quantities, outdoors,

- Road construction with NORM material,

-Building construction with NORM containing building material,

-Building construction using undiluted NORM as unshielded surface cover,

-NORM as surface layer on public places/sports grounds,

-Person living in a house with NORM containing building materials,

-Person living in a house where undiluted NORM as unshielded surface cover is used,

-External exposure to gamma emissions,

-Inhalation of dust containing radioactivity, 
-Ingestion of material, and

- Inhalation of ${ }^{222} \mathrm{Rn}$.

Groundwater pathway is also considered but the results are not reflected to set the levels, because groundwater pathways largely depend on the site conditions. ${ }^{222} \mathrm{Rn}$ concentration in air $\left(\mathrm{Bq} / \mathrm{m}^{3}\right)$ is calculated and is compared to the level of 200 $\mathrm{Bq} / \mathrm{m}^{3}$ for members of the public and $500 \mathrm{~Bq} / \mathrm{m}^{3}$ for workers, respectively.

In the derivation of level the following materials are considered:

-Waste rock,

-Ash,

- Sand,

-Slag, and

- Sludge from the oil/gas industry.

The EC concluded $300 \mu \mathrm{Sv}$ of annual effective dose incre-

Total dose (=background $+0.3 \mathrm{mSv} / \mathrm{y}$ )

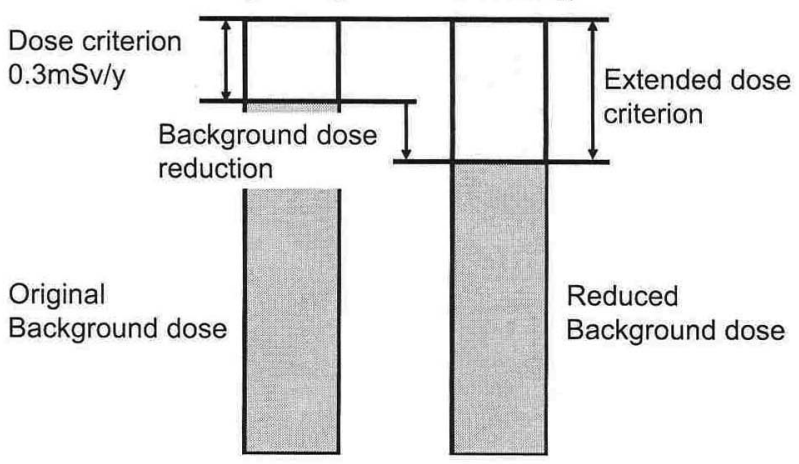

Fig. 2 Scheme for the application of the concept of background dose reduction. ment is appropriate. for natural radiation source (see Fig. 2) because $10 \mu \mathrm{Sv} / \mathrm{y}$ would in general not be practicable to implement control scheme and exemption-clearance levels for naturally occurring radionuclides should be set at a higher dose level than for practices. Grounds of dose criterion are as follows:

- Comparable to or smaller than regional variations in total effective dose from natural radiation background (external exposure only),

-Coherent with the exemption level proposed for building materials in EC RP 112, and

- Coherent with dose constraint, e. g. control of effluents.

Table 1 lists the nuclides and decay chains to be considered here. The ${ }^{238} \mathrm{U}$ chain is assumed to be in natural equilibrium with the ${ }^{235} \mathrm{U}$ chain.

In Table 2 the recommended rounded general clearance and exemption levels for all types of material are given. An additional column in Table 2 gives the (considerably higher) values only applicable for wet sludges from the oil and gas industry. The general clearance and exemption values for all materials are very much lower than those for wet sludges from oil and gas industry, essentially because the suspension/inhalation pathway can be ignored.

As a result of the large volumes of material processed and released by NORM industries, the concept of exemption and clearance are merged in this report and a single set of levels both for exemption and clearance is appropriate. Dose criteria for work activities are $300 \mu \mathrm{Sv} / \mathrm{y}$ is appropriate and $0.5 \mathrm{~Bq} / \mathrm{g}$ for $\mathrm{U}$ and $\mathrm{Th}$ in secular equilibrium is derived. This level is corresponding to the upper range of concentrations usually

Table 1 Summary of nuclides and chain segments that are used in modeling.

\begin{tabular}{|c|c|}
\hline Parent & Nuclides considered in secular equilibrium \\
\hline \multicolumn{2}{|c|}{ Uranium decay chains } \\
\hline${ }^{238} \mathrm{Usec}$ & ${ }^{238} \mathrm{U},{ }^{234} \mathrm{Th},{ }^{234 \mathrm{~m}} \mathrm{~Pa},{ }^{234} \mathrm{~Pa}(0.3 \%),{ }^{234} \mathrm{U},{ }^{230} \mathrm{Th},{ }^{226} \mathrm{Ra},{ }^{222} \mathrm{Rn},{ }^{218} \mathrm{Po},{ }^{214} \mathrm{~Pb},{ }^{214} \mathrm{Bi},{ }^{214} \mathrm{Po},{ }^{216} \mathrm{~Pb},{ }^{210} \mathrm{Bi},{ }^{210} \mathrm{Po}$ \\
\hline U nat & ${ }^{238} \mathrm{U},{ }^{234} \mathrm{Th},{ }^{234 \mathrm{~m}} \mathrm{~Pa},{ }^{234} \mathrm{~Pa}(0.3 \%),{ }^{234} \mathrm{U},{ }^{235} \mathrm{U}(4.6 \%),{ }^{231} \mathrm{Th}(4.6 \%)$ \\
\hline${ }^{230} \mathrm{Th}$ & ${ }^{230} \mathrm{Th}$ \\
\hline${ }^{226} \mathrm{Ra}+$ & ${ }^{226} \mathrm{Ra},{ }^{222} \mathrm{Rn},{ }^{218} \mathrm{Po},{ }^{214} \mathrm{~Pb},{ }^{214} \mathrm{Bi},{ }^{214} \mathrm{Po}$ \\
\hline${ }^{210} \mathrm{~Pb}+$ & ${ }^{210} \mathrm{~Pb},{ }^{210} \mathrm{Bi}$ \\
\hline $210 \mathrm{Po}$ & ${ }^{2 ! 0} \mathrm{Po}$ \\
\hline \multicolumn{2}{|c|}{ Uranium decay chains } \\
\hline${ }^{235}$ Usec & ${ }^{233} \mathrm{U},{ }^{23 !} \mathrm{Th},{ }^{231} \mathrm{~Pa},{ }^{227} \mathrm{Ac},{ }^{227} \mathrm{Th}(98.6 \%),{ }^{223} \mathrm{Fr}(1.4 \%),{ }^{223} \mathrm{Ra},{ }^{219} \mathrm{Rn},{ }^{215} \mathrm{Po},{ }^{211} \mathrm{~Pb},{ }^{211} \mathrm{Bi},{ }^{207} \mathrm{Tl},{ }^{211} \mathrm{Po}(0.3 \%)$ \\
\hline${ }^{235} \mathrm{U}+$ & ${ }^{235} \mathrm{U}_{,}{ }^{23 !} \mathrm{Th}$ \\
\hline${ }^{231} \mathrm{~Pa}$ & ${ }^{231} \mathrm{~Pa}$ \\
\hline${ }^{227}$ Acsec & ${ }^{227} \mathrm{Ac},{ }^{227} \mathrm{Th}(98.6 \%),{ }^{223} \mathrm{Fr}(1.4 \%),{ }^{223} \mathrm{Ra},{ }^{219} \mathrm{Rn},{ }^{215} \mathrm{Po},{ }^{211} \mathrm{~Pb},{ }^{211} \mathrm{Bi},{ }^{207} \mathrm{Tl},{ }^{211} \mathrm{Po}(0.3 \%)$ \\
\hline \multicolumn{2}{|c|}{ Thorium decay chains } \\
\hline${ }^{232}$ Thsec & ${ }^{232} \mathrm{Th},{ }^{228} \mathrm{Ra},{ }^{228} \mathrm{Ac},{ }^{228} \mathrm{Th},{ }^{224} \mathrm{Ra},{ }^{220} \mathrm{Rn},{ }^{216} \mathrm{Po},{ }^{212} \mathrm{~Pb},{ }^{212} \mathrm{Bi},{ }^{212} \mathrm{Po}(64.1 \%),{ }^{208} \mathrm{Tl}(35.9 \%)$ \\
\hline${ }^{232} \mathrm{Th}$ & ${ }^{232} \mathrm{Th}$ \\
\hline${ }^{228} \mathrm{Ra}+$ & ${ }^{228} \mathrm{Ra},{ }^{228} \mathrm{Ac}$ \\
\hline${ }^{228} \mathrm{Th}+$ & ${ }^{228} \mathrm{Th},{ }^{224} \mathrm{Ra},{ }^{220} \mathrm{Rn},{ }^{216} \mathrm{Po},{ }^{212} \mathrm{~Pb},{ }^{212} \mathrm{Bi},{ }^{212} \mathrm{Po}(64.1 \%),{ }^{208} \mathrm{Tl}(35.9 \%)$ \\
\hline \multicolumn{2}{|r|}{ ( } \\
\hline${ }^{40} \mathrm{~K}$ & ${ }^{40} \mathrm{~K}$ \\
\hline
\end{tabular}

sec: Parent nuclide with their decay products which are in secular equilibrium.

+ : Parent nuclide with their decay products listed in right column which are in equilibrium. nat: ${ }^{238}$ Usec and ${ }^{235}$ Usec are in their fixed natural ratio. 
Table 2 Rounded General Clearance Levels in $\mathrm{kBq} / \mathrm{kg}$.

\begin{tabular}{|l|c|c|}
\hline \multicolumn{1}{|c|}{ Nuclide $^{* 1}$} & All materials & $\begin{array}{c}\text { Wet sludge from oil } \\
\text { and gas industry }\end{array}$ \\
\hline${ }^{238}$ Usec incl. ${ }^{235} \mathrm{Usec}^{* 2}$ & 0.5 & 5 \\
\hline U nat & 5 & 100 \\
\hline${ }^{230} \mathrm{Th}$ & 10 & 100 \\
\hline${ }^{226} \mathrm{Ra}+$ & 0.5 & 5 \\
\hline${ }^{210} \mathrm{~Pb}^{1}$ & 5 & 100 \\
\hline${ }^{210} \mathrm{Po}$ & 5 & 100 \\
\hline${ }^{235} \mathrm{Usec}{ }^{* 3}$ & 1 & 10 \\
\hline${ }^{235} \mathrm{U}+$ & 5 & 50 \\
\hline${ }^{231} \mathrm{~Pa}$ & 5 & 50 \\
\hline${ }^{227} \mathrm{Ac}+$ & 1 & 10 \\
\hline${ }^{232} \mathrm{Thsec}$ & 0.5 & 5 \\
\hline${ }^{232} \mathrm{Th}$ & 5 & 100 \\
\hline${ }^{228} \mathrm{Ra}+$ & 1 & 10 \\
\hline${ }^{228} \mathrm{Th}+$ & 0.5 & 5 \\
\hline${ }^{40} \mathrm{~K}$ & 5 & 100 \\
\hline
\end{tabular}

[Note]

${ }^{* 1}$ For radionuclides considered to be in secular equilibrium see Table 1.

*2 ${ }^{238}$ Usec and ${ }^{235}$ Usec are in their fixed natural ratio (99.275 and $0.72 \%$ atomic fraction).

${ }^{* 3}$ Separate values for radionuclides of ${ }^{235} \mathrm{U}$ series are given here only for information. For NORM these values are never limiting as ${ }^{238} \mathrm{U}$ and ${ }^{235} \mathrm{U}$ are always in their fixed natural ratio.

found in ores. Therefore, regulatory control for NORM is practicable by using these levels. The ${ }^{222} \mathrm{Rn}$ concentrations were calculated based on the minimum value of all exemption/clearance levels for ${ }^{226} \mathrm{Ra}+$ for each type of material. The calculation results show the radon concentrations are below $200 \mathrm{~Bq} / \mathrm{m}^{3}$ for members of general public and $500 \mathrm{~Bq} / \mathrm{m}^{3}$ for workers for all exposure scenarios. There is possibility of contamination of groundwater as drinking water; the evaluation of doses is necessary case by case.

\section{PRESENT STATUS ON TENORM IN JAPAN}

\subsection{TENORM utilization in Japan ${ }^{8)}$}

The UNSCEAR 2000 report described the minerals containing NORM and those activities and concentrations. EC RP 122 also referred to the case where the percentage of the contents of uranium and thorium in the residues or by-products could unintentionally increase through the process of the extraction of useful materials from certain minerals. Furthermore, these minerals are chemically and physically processed and often occur in our living environment as consumer products. For these reasons, on site dose rate measurement and activity concentration analysis as to the industrial application of typical minerals and other materials and some consumer products containing NORM were performed to prepare basic information for developing exemption policies by the Nuclear Safety Division (Office of Nuclear Reactor Regulation and Office of Radiation Regulation) of MEXT.

\subsubsection{Industrial Application}

The investigation was conducted for monazite, phosphate ore, titanium minerals, bastnasite and zircon as the materials which may contain NORM with relatively high concentration, and coal as the material which is massively imported and which volume reduction is expected through the operation.

The results of analysis were summarized in Table 3 . The BSS exemption levels of ${ }^{232} \mathrm{Th}$ and ${ }^{238} \mathrm{U}$ series are $1 \mathrm{~Bq} / \mathrm{g}$. If we use $1 \mathrm{~Bq} / \mathrm{g}$ as a provisional reference criteria for activity concentrations of minerals in raw materials, monazite, phosphate ore, zircon and bastnasite exceed the reference criteria. The phosphate ores only from Jordan and Morocco exceeded the criteria. This reveals that activity concentrations of the minerals vary with the producing countries.

It was found that the dose rate at $1 \mathrm{~m}$ from the material reaches to several $\mu \mathrm{Sv} / \mathrm{hr}$ in several cases, due to the adhesion of scales or accumulation of sludge in the operation process. However, in consideration of working time, the annual dose of workers is estimated to be about $0.40 \mathrm{mSv}$ at most for the work at a bastnasite product yard. When workers handle raw material powders and other powdery substances, the amount of dust inhaled by the workers are estimated to be small because of they usually wear dust protective masks.

\subsubsection{Consumer products}

NORM-containing minerals are chemically or physically processed and often used in living environment as consumer products. Table 4 shows several examples of consumer products containing NORM with the results of analysis on activity concentrations.

They are utilized for various purposes ranging from the products with which only few people could come in contact such as pigment for painting the bottom of ships and catalyst applied to automobile mufflers to those which people could touch easily such as clothing materials and bedclothes.

As the results of the analysis, some consumer products were found to exceed the BSS exemption level. An external dose represented $110 \mu \mathrm{Sv} / \mathrm{y}$ for a radon spa bathing element, $220 \mu \mathrm{Sv} / \mathrm{y}$ for underclothes, $90 \mu \mathrm{Sv} / \mathrm{y}$ for bedding clothes (futon), $10 \mu \mathrm{Sv} / \mathrm{y}$ for wallpaper. Therefore, the external dose of a person using these consumer products may neither exceed nor reach to $1 \mathrm{mSv} / \mathrm{year}$.

\subsection{Japanese regulation on TENORM}

TENORM containing natural nuclides which activity concentration is less than $370 \mathrm{~Bq} / \mathrm{g}$ is not subject to practical regulation in the current Japanese legislative system. In the process of introduction of the concepts provided in ICRP Publ. 60 into the Japanese legislative system, the Radiation Council had its General Administrative Group launch to review incorporation of the international basic safety standards of IAEA (BSS) to the legislative system and regulations since April 1999. It submitted the report on "Exemption" to the Radiation Council in October 2002, ${ }^{9}$ noting that "exemption of NORM needs to be reviewed in the future based on investigation of their actual use in Japan and international developments." The Radiation Council decided in February, 2003 that exemption of NORM would be reviewed by the General Administrative Group. After discus- 


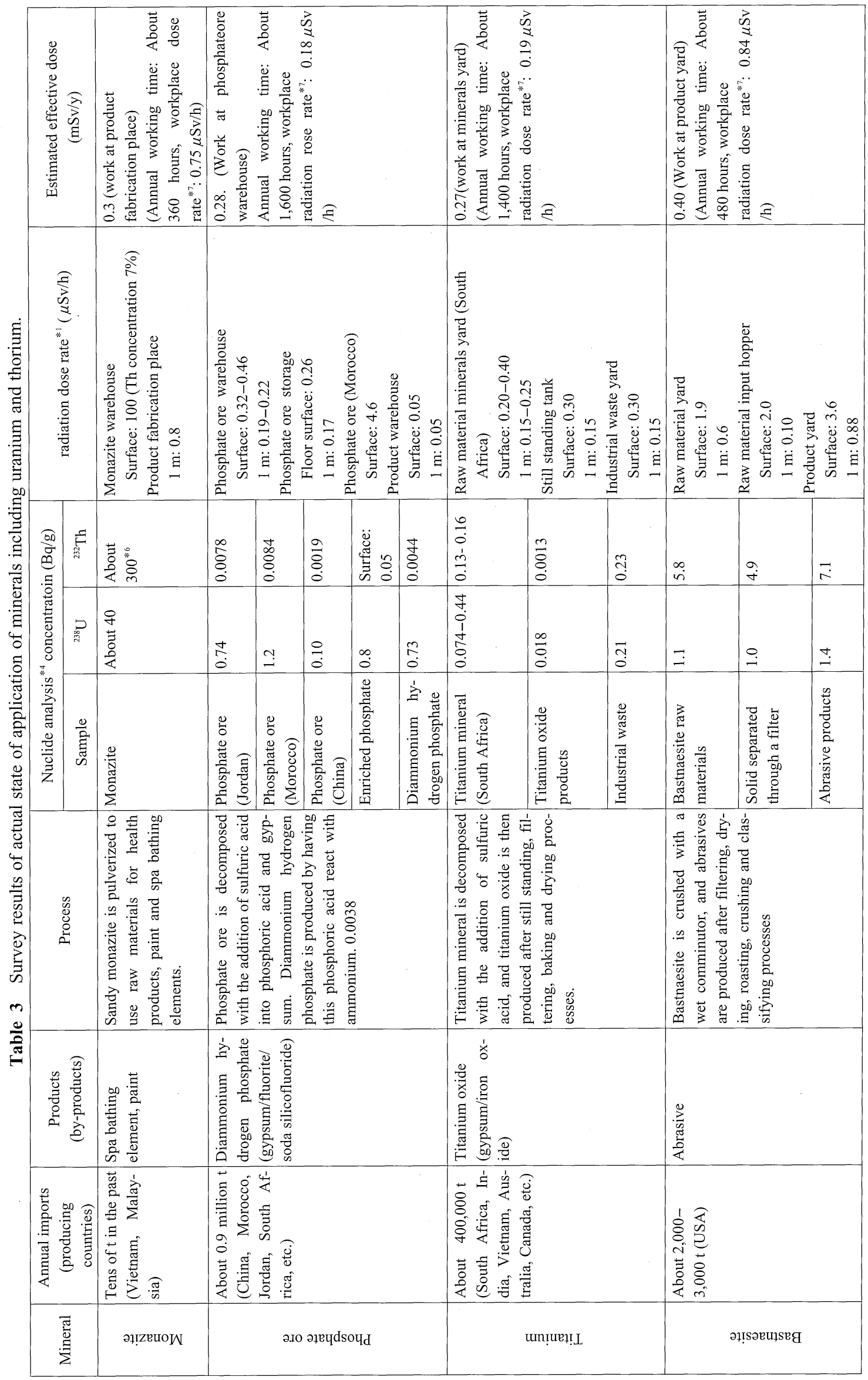




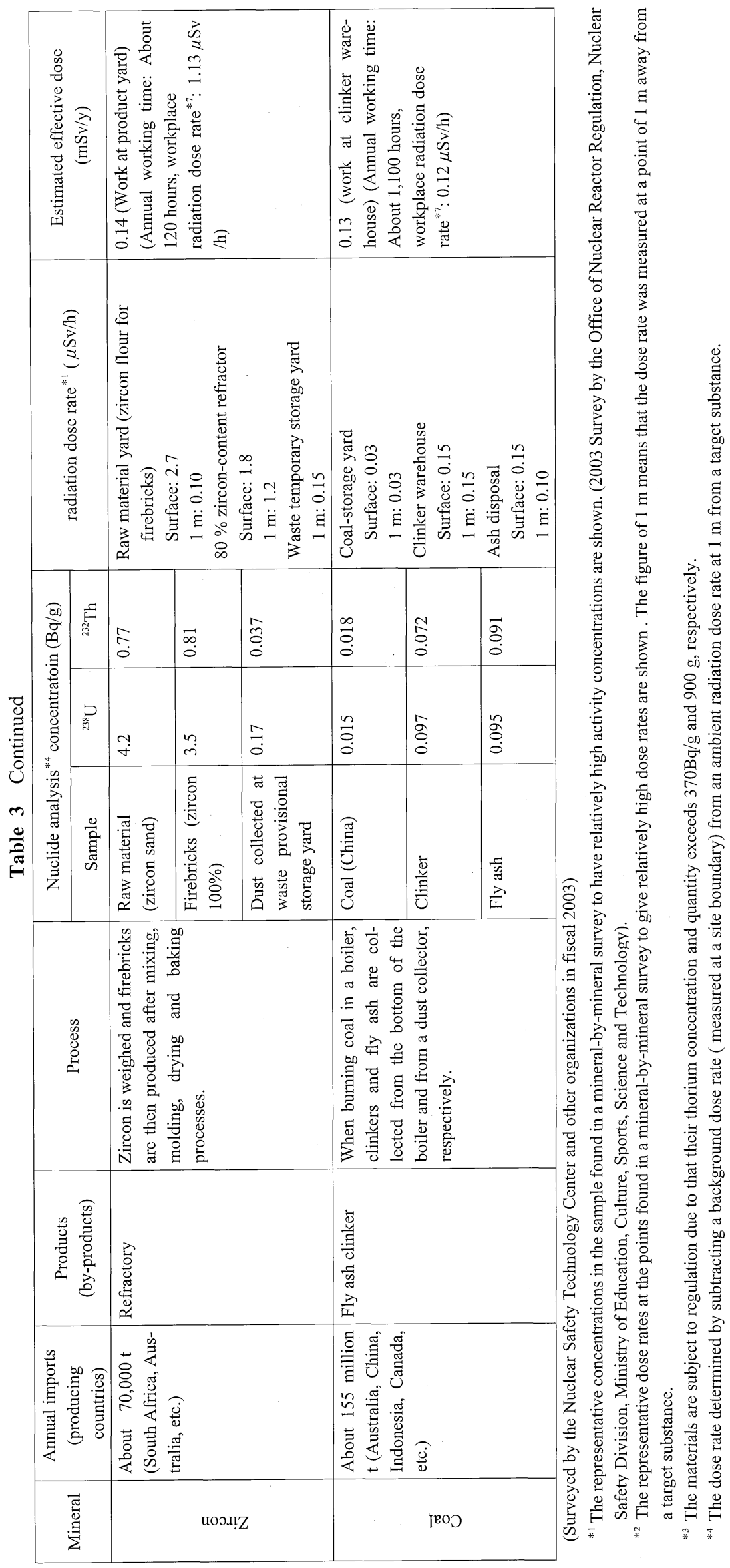


Table 4 Activity concentrations in typical consumer products.

\begin{tabular}{|l|r|r|}
\hline \multirow{2}{*}{\multicolumn{1}{|c|}{ Sample }} & \multicolumn{2}{|c|}{ Analysis results (activity concentration): (Bq/g) } \\
\cline { 2 - 3 } & ${ }^{238} \mathrm{U}$ & \multicolumn{1}{c|}{${ }^{232} \mathrm{Th}$} \\
\hline Radon spa bathing element A & 34 & 270 \\
Ship bottom paint pigment & 12 & 81 \\
Radon spa bathing element B & 10 & $12-71$ \\
Bracelet/necklace (ceramics) & $1.7-8.8$ & 34 \\
Health appliances (containing powders) & 5.4 & $0.49-0.57$ \\
Refractory fire brick & $2.9-3.5$ & 210 \\
Muffler catalyst & 3.3 & 8.8 \\
Clothes (incorporating NORM in fabrics) & 1 & $0.093-8.5$ \\
Supporter/wristband (incorporating NORM in fabrics) & $0.011-0.94$ & $2.9-5.5$ \\
Odor-eating paint & $0.4-0.82$ & 6.2 \\
Socks (incorporating NORM in fabrics) & 0.7 & 5.4 \\
Seat (incorporating NORM in fabrics) & 0.67 & $0.63-6.2$ \\
Shoe socking (containing powders) & $0.085-0.42$ & $0.01-2.3$ \\
Bedclothes (incorporating NORM in fabrics) & $0.043-0.26$ & 0.7 \\
Abrasive & 0.2 & $0.0014-0.0015$ \\
Phosphate fertilizer & $0.038-0.073$ & $0.00081-0.029$ \\
Sinter or mineral encrustations left by hot springs & $0.00084-0.012$ & \\
\hline
\end{tabular}

(Surveyed by the Nuclear Safety Technology Center and other organizations in fiscal 2002)

sions in the nine meetings, the Group submitted the report in October 2003. ${ }^{8)}$

The report describes the results of investigation on status of actual use of NORM in Japan. Various kinds of minerals, monazite, phosphate rock, titanium ore and etc. with radionuclides of Uranium and Thorium series and ${ }^{147} \mathrm{Sm}$ were found to be widely used for industrial purpose. The annual dose to workers handling these materials would not exceed 1 $\mathrm{mSv} /$ year. Ship bottom paint and various kinds of health promoting product such as apparatus for artificial hot spring, clothes, bedclothes, etc. were used as consumer products in Japan. The estimated dose of users due to these materials would not exceed $10 \mu \mathrm{Sv} / \mathrm{y}$ under normal conditions of use.

The Group discussed concept for future regulation of NORM in Japan. Use of NORM would not be only related to "practice" but also subject to "intervention." NORM out of control in essential (including radiation sources present in the environment such as soil and ${ }^{40} \mathrm{~K}$ in the body) should be "excluded" from the scope of regulation. NORM, extending from those with a very low level of radioactivity to those causing significant exposure, are broadly distributed in the general environment and show extensively different ranges of radioactivity concentration. Therefore, it is difficult to regulate them by establishing an uniform exemption level of concentration. Various types of raw materials containing NORM are widely used without awareness of their radioactivity. They would be considered to be existing sources which would be subject to intervention.

Taking into account these points of view, actual use of NORM should be classified by artificiality or possibility of actual exposure. Then adequate methods of regulation, exemption or intervention exemption may be necessary to be determined in accordance with their characteristics based on the radiation dose. Approaches based on the radiation dose instead of the amount or the concentration should be established. Table 5 show Classification of NORM. Categories 1, 2 and 3 should be exempted from regulation. Categories 4, 5 and 6 should be newly subject to regulation. Categories 7 and 8 were excluded from consideration of exemption by the General Administrative Group this time.

\subsection{Some events related to TENORM}

Some events related to TENORM were reported in these years. The examples of those events were the waste from uranium mining and milling and titanium residue, the storage of large amount of monazite ore, some consumer products using NORM (air purification device, artificial radon spa) etc. Almost all events were taken up as a scandal by the mass media even in the no illegal case. There could be pointed out the importance of (1) the provision of countermeasure corresponding to the situation and (2) the enlightenment and education of the general public on the knowledge of radiation.

\subsubsection{NORM waste from uranium mining and milling facility}

A reclamation program on waste generated from uranium mining and milling at the Ningyo-toge, Okayama, Japan is being conducted (Fig. 3). Related wastes are mainly composed of uranium mill tailings and waste rocks left after a domestic exploitation project from mid 50's to late 80 's. Dismantling debris that will be generated from the decommissioning of mining facilities is also expected (Table 6). Currently, they are maintained for the purpose of environmental protection including radiological and non-radiological hazard in accordance with the Mine Safety Law (MSL). Regarding radiological hazard, management of these waste is currently controlled by the limit of $1 \mathrm{mSv} / \mathrm{a}$ at site boundaries under MSL, and would be also applied a policy regarding 
Table 5 Classification of and proposed approaches to materials containing NORM.

\begin{tabular}{|c|c|c|c|c|c|c|}
\hline \multicolumn{3}{|c|}{ Category (examples) ${ }^{* 1}$} & $\begin{array}{c}\text { Exclusion, practice or } \\
\text { intervention }\end{array}$ & $\begin{array}{c}\text { Regulation by } \\
\text { legislation system }\end{array}$ & Approaches & $\begin{array}{l}\text { Dose target/criteria } \\
\text { to take approaches }\end{array}$ \\
\hline 1 & \multicolumn{2}{|c|}{$\begin{array}{l}\text { Raw materials such as mineral ore } \\
\text { without procedure of enhancing } \\
\text { concentration. } \\
\text { ( except categories } 2,3,4,5 \text { and } 6 \text { ). }\end{array}$} & Exclusion & Not regulated & - & - \\
\hline 2 & \multicolumn{2}{|c|}{$\begin{array}{l}\text { Waste rock residues from past mine or } \\
\text { industrial activities. }\end{array}$} & Intervention & Not regulated & $\begin{array}{l}\text { Action level will be } \\
\text { considered }\end{array}$ & $\begin{array}{l}\text { Examined in the } \\
\text { future }(1-10 \mathrm{mSv} / \mathrm{y})\end{array}$ \\
\hline 3 & \multicolumn{2}{|c|}{$\begin{array}{l}\text { Ash, scale, etc. produced by industries } \\
\text { (concentration of substances treated as } \\
\text { raw materials should be exemption level } \\
\text { or below) }\end{array}$} & Intervention & Not regulated & $\begin{array}{l}\text { Action level will be } \\
\text { considered }\end{array}$ & $\begin{array}{l}\text { Examined in the } \\
\text { future }(1-10 \mathrm{mSv} / \mathrm{y})\end{array}$ \\
\hline 4 & \multicolumn{2}{|c|}{$\begin{array}{l}\text { Soil from mines currently in operation } \\
\text { and industrial residues (disposal) } \\
\text { (monazite, bastnasite (polishing agent), } \\
\text { zircon, tantalite, phosphate rock, samar- } \\
\text { ium, uranium ore, thorium ore, titanium } \\
\text { ore, coal ash (including fly ash), other ma- } \\
\text { terials for consumer products, etc.) }\end{array}$} & Practice/Intervention $* 2$ & Regulated & $\begin{array}{l}\text {-Identify materials } \\
\text { possibly exceeding a } \\
\text { certain level of } \\
\text { concentration } \\
\text { - Seek for adequate } \\
\text { management in terms } \\
\text { of radiological } \\
\text { protection on use of } \\
\text { special materials } \\
\text { depending on doses } \\
\text { received by workers } \\
\text { or public. }\end{array}$ & $\begin{array}{l}1 \mathrm{mSv} / \mathrm{y} \text { (examine } \\
\text { whether to regulate or } \\
\text { intervene if this value } \\
\text { is exceeded.) }\end{array}$ \\
\hline 5 & \multicolumn{2}{|c|}{$\begin{array}{l}\text { Raw materials for industrial use } \\
\text { (manufacture, energy production and } \\
\text { mining) (excluding Category } 7 \text { ) }\end{array}$} & Practice/intervention $* 2$ & Regulated & Same as in Category 4 & $\begin{array}{l}1 \mathrm{mSv} / \mathrm{y} \text { (same as } \\
\text { above) }\end{array}$ \\
\hline 6 & \multicolumn{2}{|c|}{$\begin{array}{l}\text { Consumer products (usage) (Artificial hot } \\
\text { spring elements, health appliances, } \\
\text { bedclothes, clothes, paint, mantle, catalyst } \\
\text { for automobiles, refractory, polishing } \\
\text { agent, fertilizer, mineral deposit of hot } \\
\text { springs, etc.) }\end{array}$} & Practice & $\begin{array}{l}\text { Examine whether to } \\
\text { regulate or not for } \\
\text { each material }\end{array}$ & $\begin{array}{l}\text { Apply BSS exemption } \\
\text { level basically } \\
\text { Examine a system } \\
\text { corresponding with } \\
\text { type approval }\end{array}$ & $\begin{array}{l}10 \mu \mathrm{Sv} / \mathrm{y} \\
1 \mathrm{mSv} / \mathrm{y}\end{array}$ \\
\hline 7 & \multicolumn{2}{|c|}{$\begin{array}{l}\text { Nuclear fuel material refined to inten- } \\
\text { tionally use its nature of emitting radiation } \\
\text { and material to be used as radiation source }\end{array}$} & Practice & Regulated & $\begin{array}{l}\text { Apply BSS exemption } \\
\text { level }\end{array}$ & $10 \mu \mathrm{Sv} / \mathrm{y}$ \\
\hline \multirow[t]{3}{*}{8} & \multirow[t]{3}{*}{ Radon } & $\begin{array}{l}\text { Radon generated from } \\
\text { radium source under } \\
\text { regulation }\end{array}$ & Practice & Regulated & $\begin{array}{l}\text { Apply BSS exemption } \\
\text { level }\end{array}$ & - \\
\hline & & $\begin{array}{l}\text { Radon in occupational } \\
\text { environments of mine for } \\
\text { nuclear source materials }\end{array}$ & Practice & $\begin{array}{l}\text { Regulated by the } \\
\text { Mine Safety Law }\end{array}$ & - & - \\
\hline & & $\begin{array}{l}\text { Radon in general } \\
\text { environments such as } \\
\text { residence and general work } \\
\text { place excluding that } \\
\text { mentioned above }\end{array}$ & Intervention & Not regulated & Action level & $\begin{array}{l}\text { Examined in the } \\
\text { future }\end{array}$ \\
\hline
\end{tabular}

${ }^{* 1}$ Examples cited here are findings of review of literature and investigation of actual conditions conducted on materials possibly containing a relatively greater amount of NORM. Contents of naturally occurring radioactive material differ depending on area of production, type, physical quantities of materials or minerals. Therefore, in Categories 4 and 5, those which may exceed a certain level of concentration will be identified and then, those requiring radiation protection will be subjected to an appropriate management.

${ }^{* 2}$ Basically it is practice, but has both elements of practice and intervention; in the initial process that treats raw materials, elements requiring intervention represent a larger portion.

${ }^{* 1}$ Categories 7 and 8 have been excluded from consideration of exemption by the General Administrative Group this time. 
Table 6 Major characteristic on waste.

\begin{tabular}{|c|c|c|c|}
\hline Waste & Volume & $\begin{array}{c}\text { Average U } \\
\text { concentration (Bq/g) }\end{array}$ & $\begin{array}{c}\text { Average }{ }^{226} \mathrm{Ra} \\
\text { concentration }(\mathrm{Bq} / \mathrm{g})\end{array}$ \\
\hline Waste rock (17 sites) & ca $200,000 \mathrm{~m}^{3}$ & $<0.09-0.42$ & - \\
\hline Mill tailings & ca $34,000 \mathrm{~m}^{3}$ & ca 3 & ca 16 \\
\hline $\begin{array}{c}\text { Heap leaching facility*1 } \\
\text { (tank, valve, ion exchange } \\
\text { resin, concrete, etc) }\end{array}$ & ca 10,000 drums (estimated) & - & - \\
\hline
\end{tabular}

${ }^{* 1}$ Demolition of heap leaching facility is now under consideration, therefore waste volume described here is based on estimation. Radionuclides contained in waste rock are considered to be uranium and its progeny, whereas mill tailings that is residue of ore extracted by sulfuric acid, is depleted in uranium only (relatively rich in 226Ra).

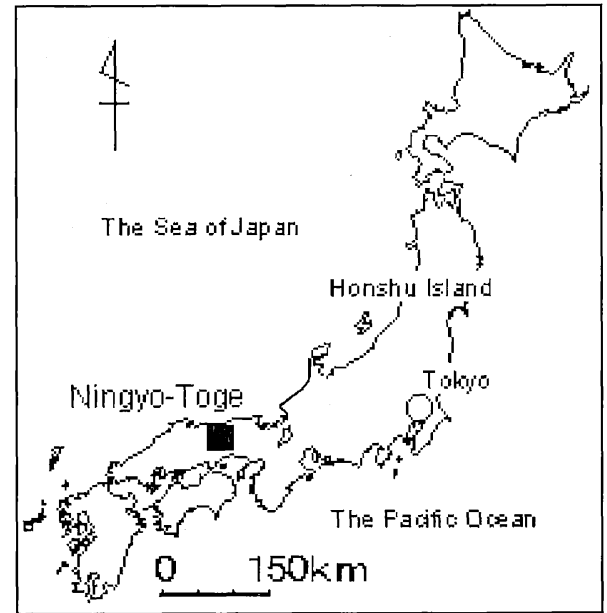

Fig. 3 Locality of Ningyo-toge.

exemption of NORM/TENORM formulated by the Radiation Council in 2003. Radionuclides in the waste consist of uranium-series with long half-lives, and require long-term waste management. Measures will be principally carried out with encapsulation in accordance with MSL which is similar to remediation measures on uranium mill tailings and mining sites applied in several countries (Fig. 4). The objectives of the site measures are; solids containment, control of radiation exposure, control of radon gas, control of liquids, stability and integrity of site structures. Monitoring and surveillance will be carried out in every phase of the reclamation in order to verify the efficiency of site measures. Management of the site would be maintained under the institutional control.

Concept of measures has been established with a perspective through safety analysis after a series of discussion at boards consisting of specialists and experts from other organizations. Current phase is the stage to perform various field measurements, laboratory-scale tests and demonstration-scale tests in order to collect data for safety analysis and site designing including analysis to evaluate site stability.

A current topic of the program is on measures of waste rock in the Katamo site, one of 17 yards around the Ningyotoge (Fig. 5). Following a decision of the Supreme Court, it is required to displace waste rock from the yard, which was estimated about $3,000 \mathrm{~m}^{3}$ according to an agreement between a local community and the Power Reactor and Nuclear Fuel Development Corporation, former JNC, in 1990. Radioactivity of the waste rock is equivalent to the part of higher than

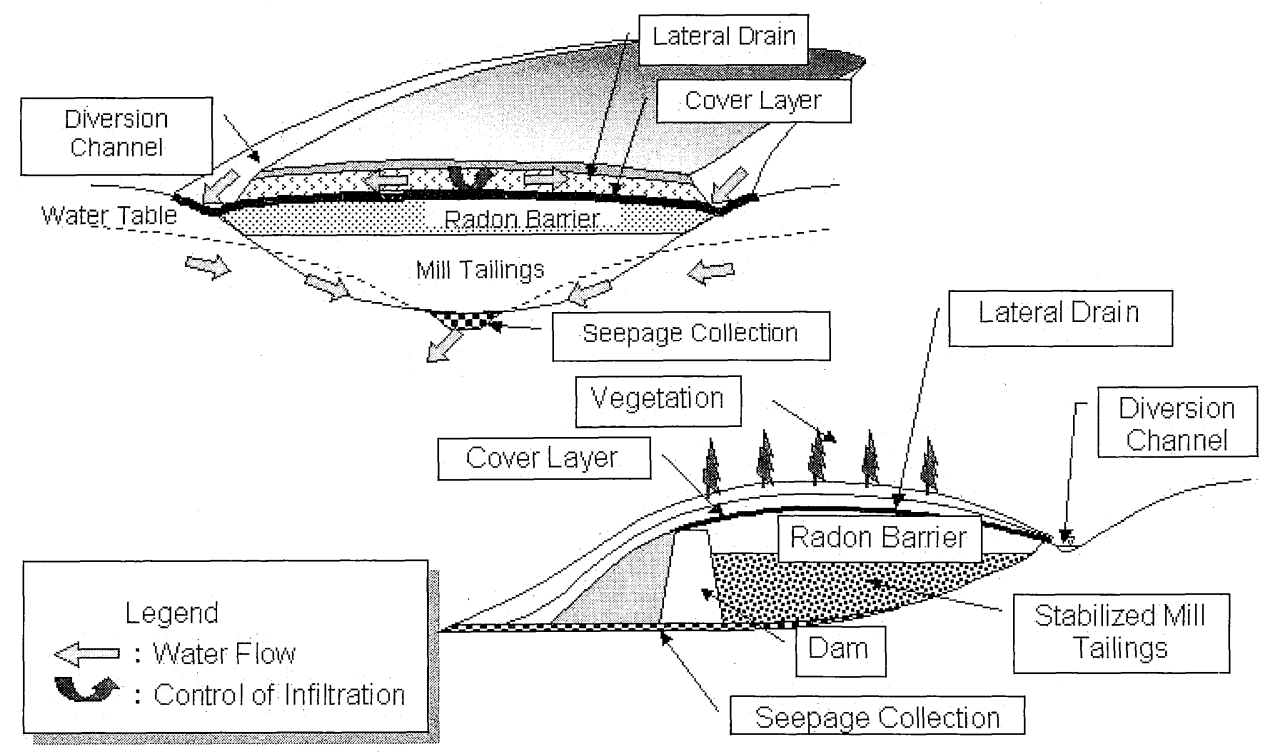

Fig. 4 Suppositional measures on uranium mill tailings. 


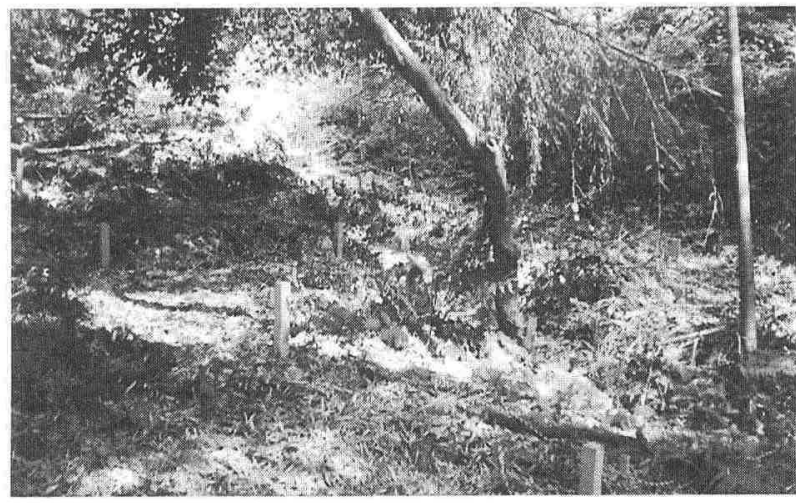

Fig. 5 View of a waste rock yard. Spatial gamma dose rate was measured at every wooden mark to characterize the waste rock of the Katamo site. Each mark indicates each intersection of 2 meter grid.

$0.3 \mu \mathrm{Sv} / \mathrm{h}$. Suppositional measures would be displacement and disposal in an inclined shaft or a shaft with plugging. The site and methodology for disposal does not come to an agreement with interested parties i. e. local communities and/or local governments, and JNC due to difference of their opinions.

\subsubsection{Storage of large amount of monazite ore}

The existence of the monazite ore was clarified in June, 2000 by the investigation of the police in several places in the country starting with the fact that suspicious mails which enclosed the powder of the monazite ore had been sent to the official residence etc.

Science and Technology Agency (STA, present MEXT) received the report from the police, investigated the situation of its storage on each site, confirmed safety, and guided the owner to manage it appropriately.

The surface dose rates of the container and the door in the building in which the monazite ore was put were several tens $\mu \mathrm{Sv} / \mathrm{h}$ at the maximum, and some of the monazite ore contained the thorium weighing more than $100 \mathrm{~kg}$, which needed the written report of use as the nuclear source material.

The whole picture of the monazite and the intention of the use by the owner was confirmed by the investigation, and the written report of the use of the monazite ore in two places as the nuclear source material was performed.

In response to the above-mentioned problem, STA reported on "Appropriate management of the radioactive materials" including the following contents at the end of 2000 .

- The appropriate united system on the management of the nuclear source materials that aren't used for energy with the management of other radioisotopes is to be examined in the future from the viewpoint of the prevention from radiation hazard.

-The clarification of the exclusion and the exemption of the material with low dose level from regulatory control is to be aimed at as maintenance of the standard concerning the radioactive materials to be controlled based on the international discussion.

\section{PROBLEMS TO BE SOLVED}

The flow toward the NORM/TENORM solution could be summarized as following steps.

[Step 1: The conceptual understanding is essential for a stable solution of NORM/TENORM problem.]

In case of the practice, like radioactive waste disposal, the base is a dose limitation to general public as $1 \mathrm{mSv} / \mathrm{y}$ based on ICRP Publ. 60. As a dose constraint for a practice of radioactive waste disposal, the recommended value of $0.3 \mathrm{mSv} / \mathrm{y}$ is given in the ICRP Publ. 77. ${ }^{(0)}$ But as a free release value for radio-nuclide contained consumer goods, an exemption value; $10 \mu \mathrm{Sv} / \mathrm{y}$ is used for a measure of safety. Nearly the same situation appears in IAEA-RS-G-1.7 as a clearance level for a big volume, but extremely low level radioactive waste from a decommissioning of nuclear facilities.

On the other hand, in case of NORM/TENORM discussion, exclusion and intervention concepts are inevitable for making-up guideline of NORM/TENORM. The exclusion is based on a uncontrollability of sources, and the intervention guidelines ( $1 \mathrm{mSv} / \mathrm{y}$ : intervention exception level, $10 \mathrm{mSv} / \mathrm{y}$ : intervention start line, $100 \mathrm{mSv} / \mathrm{y}$ : intervention obligation line) are based on ICRP Publ. 82 for the protection guideline under a long term public exposure.

[Step 2: Fact finding of NORM/TENORM based on the scientific data.]

Generic information is important for the real understanding of nature and making up a classification of radioactivity and radiation level for NORM/TENORM. These generic information are collected in UNSCEAR report under worldwide surveys. Data collection based on the documents is also important for the purpose of incorporating an each region and country's situation.

[Step 3: Measurement of radioactivity and radiation.]

A specific data collection of radioactivity $(\mathrm{Bq} / \mathrm{g}$ or $\mathrm{MBq} / \mathrm{t})$ and radiation $(\mu \mathrm{Sv} / \mathrm{h}$ or $\mathrm{mSv} / \mathrm{y})$ through real measurements is valuable. These on site measurements give us a direction to the next step.

[Step 4: Characterization of NORM/TENORM and Categorization of Levels.]

Depending on a form of existence, a purpose of use and a level of radiation, a characterization or a categorization is possible on NORM/TENORM. One side end has a strong trend of exclusion for the reason of unamenability of control. On the other end has a strong trend of practice for the reason of usual application as consumer's goods. To these continuous changing situations, Japanese radiation council has already given of 6 categories based on the consideration of practice and intervention as mentioned before for the guideline of NORM/TENORM.

[Step 5: Indication of countermeasures and setting regulations if necessary.]

Several countermeasures are conceivable; a simple shielding of stockyard, a soil cover of repository site, a preparation of simple mask for the protection of workers. All of these are countermeasures for the extreme condition of NORM/ 
TENORM. If necessary, a guideline, a regulation or a law should be prepared depending on the situations based on the categorization by dose (Sv) or activity $(\mathrm{Bq})$

[Step 6: Application to the real scene.]

The application of countermeasures based on the categorization should be easy to understand. For an administrative management, a checklist system listing requirements will be helpful for an on-site application of these countermeasures.

\section{CONCLUSION}

On NORN/TENORM, radiation protection principles are summarized in this paper based on ICRP and IAEA. The figures of on site use of these materials are summarized depending on the using conditions. The recent activities of Japanese Radiation Council; based on NORM/TENOTRM categorization, are shown as a real example of categorization. The case study is also expanded for the discussion of the applicability. The discussion items and the flow toward the NORM/ TENORM solution are also developed.

\section{REFERENCES}

1) International Commission on Radiation Protection; ICRP Publication 60: 1990 Recommendations of the International Commission on Radiation Protection (adopted 1990), Ann. ICRP, 21, (1-3), (1991).

2) United Nations Scientific Committee on the Effects of Atomic Radiation; Sources and effects of ionizing radiation, UNSCEAR 2000 Report to the General Assembly, with scientific annexes, (2000).

3) IAEA; International Basic Safety Standards for Protection against Ionizing Radiation and for the Safety of Radiation Sources, Safety Series No. 115 (1996).

4) International Commission on Radiation Protection; ICRP
Publication 82: Protection of the public in situations of prolonged radiation exposure, Ann. ICRP, 29(1-2), (1999).

5) International Commission on Radiation Protection; ICRP Publication 75: General Principles for the radiation protection of workers, Ann. ICRP, 2(1), (1997).

6) IAEA; Application of the Concepts of Exclusion, Exemption and Clearance, Safety Standards Series No. RS-G$1.7,(2004)$.

7) The European Commission: Radiation Protection No. 122 Part II, "Practical use of the concepts of clearance and exemption (Part II) -Application of the concepts of exemption and clearance to natural radiation sources-", (2002).

8) Japanese Radiation Council: On the regulatory exemption of natural occurring radioactive material, Report of Japanese Radiation Council, (2003). (In Japanese)

9) Japanese Radiation Council: On the regulatory exemption, Report of Japanese Radiation Council, (2002). (In Japanese)

10) International Commission on Radiation Protection; ICRP Publication 77: Radiological protection policy for the disposal of radioactive waste, Ann. ICRP, 27 (Suppl.), (1997).

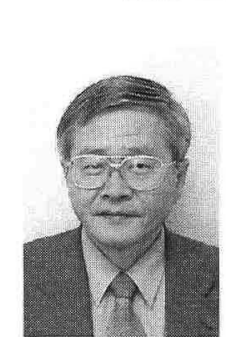

Toshiso Kosako

FNCA RWM Project Leader of Japan. Associate Professor (Nuclear Engineering), Research Center for Nuclear Science and Technology, The University of Tokyo. 